\title{
Supraglacial lakes on the Greenland ice sheet advance inland under warming climate
}

\author{
A. A. Leeson ${ }^{1,2 \star}$, A. Shepherd ${ }^{1}$, K. Briggs' ${ }^{1}$, I. Howat ${ }^{3}$, X. Fettweis ${ }^{4}$, M. Morlighem ${ }^{5}$ and E. Rignot ${ }^{5}$
}

Supraglacial lakes (SGLs) form annually on the Greenland ice sheet ${ }^{1,2}$ and, when they drain, their discharge enhances ice-sheet flow $^{3}$ by lubricating the base ${ }^{4}$ and potentially by warming the ice ${ }^{5}$. Today, SGLs tend to form within the ablation zone, where enhanced lubrication is offset by efficient subglacial drainage ${ }^{6,7}$. However, it is not clear what impact a warming climate will have on this arrangement. Here, we use an SGL initiation and growth ${ }^{8}$ model to show that lakes form at higher altitudes as temperatures rise, consistent with satellite observations ${ }^{9}$. Our simulations show that in southwest Greenland, SGLs spread 103 and $110 \mathrm{~km}$ further inland by the year 2060 under moderate (RCP 4.5) and extreme (RCP 8.5) climate change scenarios, respectively, leading to an estimated 48-53\% increase in the area over which they are distributed across the ice sheet as a whole. Up to half of these new lakes may be large enough to drain, potentially delivering water and heat to the ice-sheet base in regions where subglacial drainage is inefficient. In such places, ice flow responds positively to increases in surface water delivered to the bed through enhanced basal lubrication ${ }^{4,10,11}$ and warming of the ice ${ }^{5}$, and so the inland advance of SGLs should be considered in projections of ice-sheet change.

The volume of water stored in SGLs on the surface of the Greenland ice sheet is determined by the presence of depressions in the local terrain ${ }^{2}$, by the amount of runoff (melt water plus $^{8}$ rain minus refreezing in the snowpack) and by lake drainage ${ }^{3}$. It is estimated that $13 \%$ of Greenland's SGLs drain on timescales of the order of a few hours ${ }^{12}$, often by the creation of moulins as waterfilled fractures propagate through the full thickness of the ice sheet (termed hydro-fracture ${ }^{13}$. SGLs act as a source of en- and subglacial water when they drain and afterwards, the moulin acts as a conduit allowing runoff to pass between the ice-sheet surface and base $\mathrm{e}^{1,3}$. Satellite and ground-based observations show a correlation between the degree of runoff and the rate of ice motion ${ }^{4,6,7}$; however, there are known spatial and temporal variations in the magnitude and sign of this relationship. For example, near the ice-sheet margin, lower annual ice speeds have been recorded in years of high melting ${ }^{6,7}$ but further inland-at higher elevations-the reverse seems to be the case $\mathrm{e}^{4,11}$. This dichotomy can be attributed to an abundance of melt water at the margin, enabling the evolution of efficient subglacial drainage early in the melt season ${ }^{6,10}$, and thicker ice and less water farther inland hindering the development of an efficient evacuation system ${ }^{14,15}$. In addition to their impact on basal sliding, draining SGLs, and moulins that persist post-drainage, can exert a local warming as relatively warm water passes through the colder ice (termed cryo-hydrologic warming) ${ }^{5}$. This-by rendering the ice sheet more fluid-can potentially enable faster ice-sheet flow due to internal deformation ${ }^{5}$. Ultimately, faster flow may result in mass loss as ice-sheet thinning promotes an inland expansion of the melt zone.

In southwest Greenland, the maximum elevation at which SGLs occur has migrated $53 \mathrm{~km}$ inland over the past 40 years, following an upwards shift in the ice-sheet equilibrium line ${ }^{9}$, which, historically, has fallen close to (within $10 \mathrm{~km}$ on average) the maximum elevation of SGLs (Supplementary Table 1). This migration has accelerated over the past two decades, in response to rapid changes in regional temperature ${ }^{16}$ associated with global warming and an increase in frequency of negative North Atlantic Oscillation indices during boreal summer (favouring warmer and drier atmospheric conditions than normal) ${ }^{17}$. To study the long-term response of SGLs to this and future climate change, we simulate their initiation and growth over the period 1971-2060 in the vicinity of the Russell and Leverett glaciers (Fig. 1). Our simulations are performed using the SGL Initiation and Growth (SLInG) model $^{8}$, a hydrologic model that routes runoff over a model of the ice-sheet surface, allowing water to form lakes in topographic depressions (Methods). Here we focus on a $19,441 \mathrm{~km}^{2}$ section of the ice sheet situated at elevations more than $1,100 \mathrm{~m}$ above sea level (a.s.l.), where subglacial drainage is expected to be inefficient ${ }^{10,15}$ and the impact of SGLs on ice-sheet hydrology is potentially large. The SLInG model is forced with estimates of runoff derived from high-resolution $(25 \mathrm{~km})$ regional climate model $^{18}$ reanalyses (1971-2010) and future projections (2006-2100). Future simulations are performed under both moderate and extreme climate projections characterized by Intergovernmental Panel on Climate Change Representative Concentration Pathways (RCPs) 4.5 and 8.5 (ref. 19), respectively.

Our model predicts that the maximum elevation at which SGLs occur has migrated $56 \mathrm{~km}$ inland in our study area since the 1970s (Fig. 2), in excellent agreement with an independent estimate $(53 \mathrm{~km})$ based on satellite observations acquired over the same region ${ }^{9}$. Both data sets reveal that the rate of inland migration was slow $\left(0.5 \mathrm{~km} \mathrm{yr}^{-1}\right)$ and steady until 1995 , and that it accelerated sharply thereafter to its present rate of $3.0 \mathrm{~km} \mathrm{yr}^{-1}-\mathrm{a}$ sixfold increase. The step change was in response to enhanced surface melting associated with a $2.2^{\circ} \mathrm{C}$ air temperature rise over the same period, with respect to the average before then ${ }^{16}$. The maximum SGL elevation in our past and present simulations exhibits a small (6\%) bias with respect to the observations, and agreement between the two estimates is generally very good $\left(r^{2}=0.74\right)$. During a six year period (2006-2012) when model simulations and satellite observations are both available, the agreement is even

\footnotetext{
${ }^{1}$ School of Earth and Environment, University of Leeds, Leeds LS2 9JT, UK. ${ }^{2}$ Department of Geography, Durham University, Durham DH1 3LE, UK. ${ }^{3}$ School of Earth Sciences and Byrd Polar Research Center, Ohio State University, Columbus, Ohio 43210, USA. ${ }^{4}$ University of Liège, Department of Geography, 2, Allée du 6 Août, Bat. B11, 4000 Liège, Belgium. ${ }^{5}$ Department of Earth System Science, University of California, Irvine, 3200 Croul Hall, Irvine, California 92697-3100, USA. *e-mail: a.a.leeson@leeds.ac.uk
} 


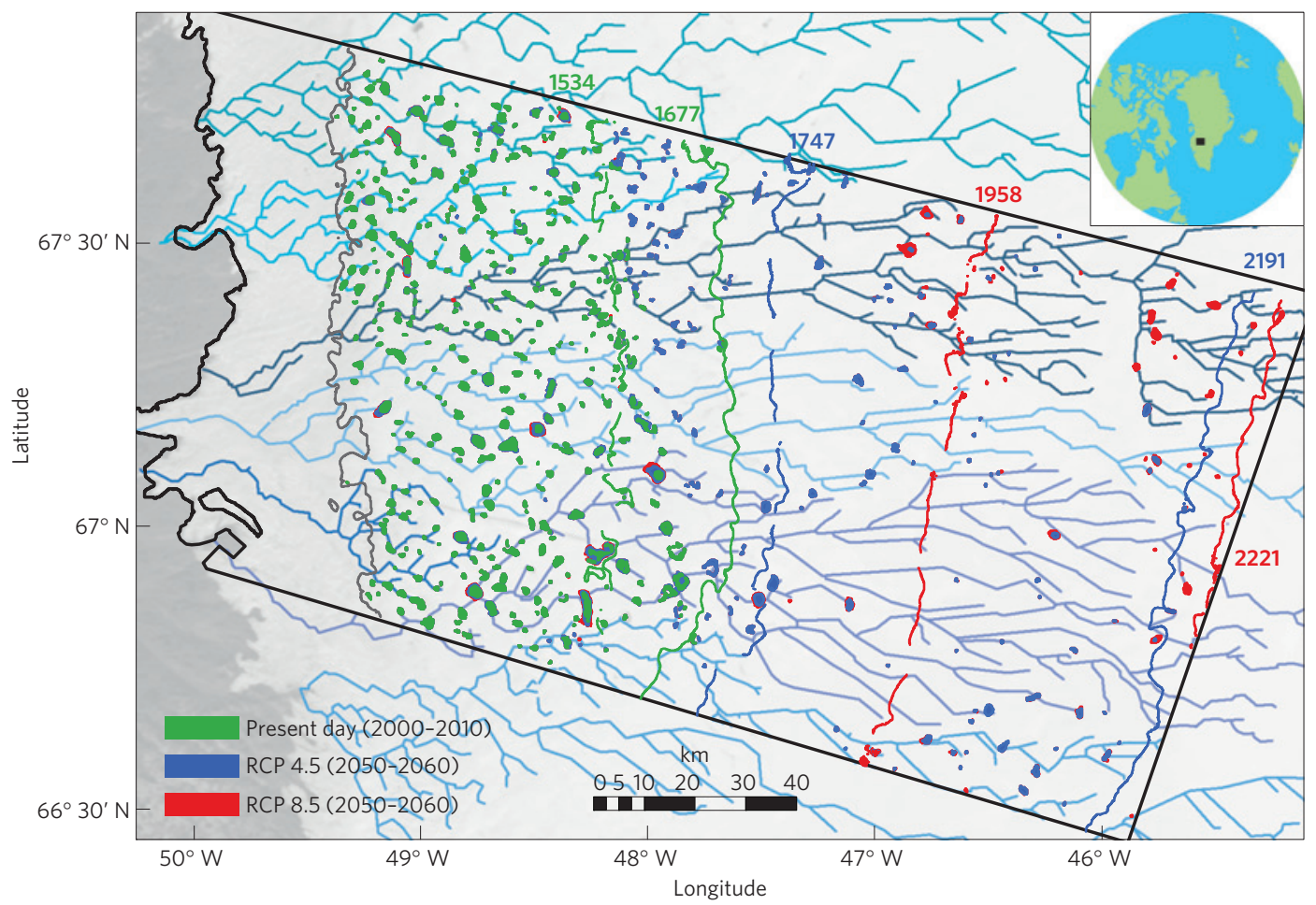

Figure 1 | Simulated distribution of SGLs in 2050-2060 under projections of climate change. Coloured shapes indicate new lakes that appear in each scenario. Black outline indicates SLInG model domain; contours indicate: lower limit of reported results (charcoal), maximum elevation of lakes (solid colours) and the elevation of the 90th percentile of lake area (dashed colours). Likely subglacial drainage pathways are indicated in blue; shades represent discrete catchments. The background is a Moderate Resolution Imaging Spectrometer image, captured in September 2003.

a

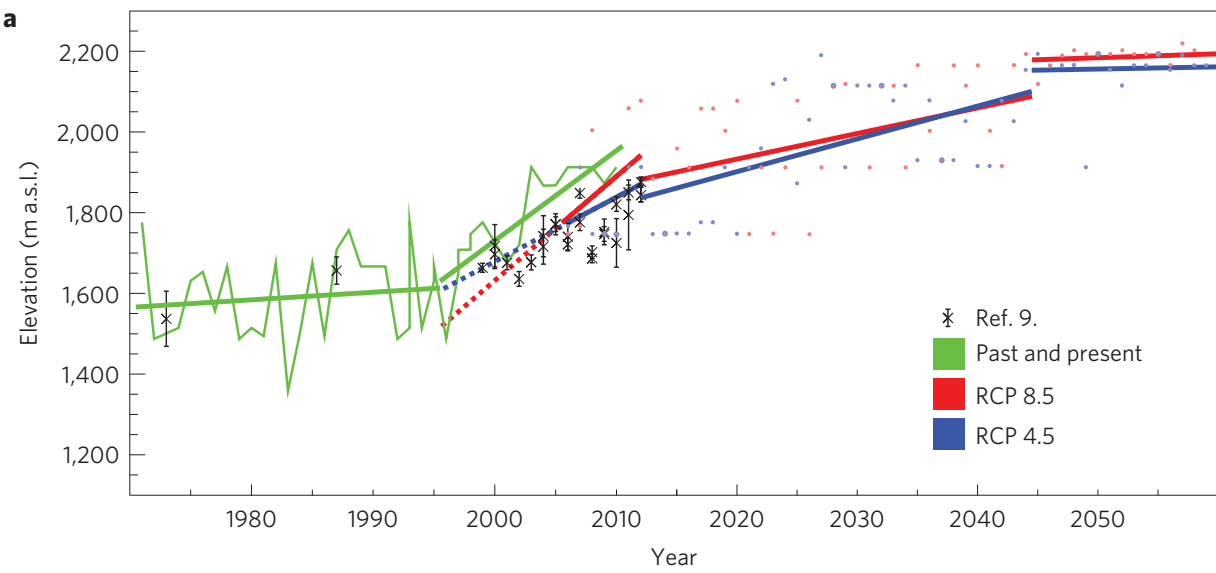

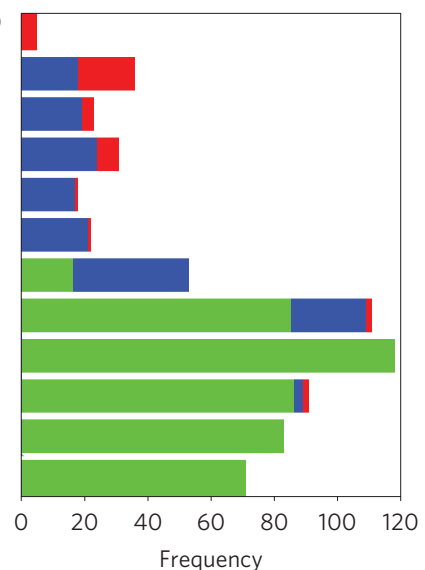

Figure 2 | Simulated and observed trends in maximum lake elevation. a, Comparison of model output and satellite observations for the 1971-2060 period, under two climate change scenarios. A linear fit has been applied to both data sets and indicates an upwards trend in maximum lake elevation. The dotted lines denote a backwards projection from the fit. b. Histogram of decadal average lake distribution; past and present scenario considers 2000-2010; RCPs 4.5 and 8.5 consider 2050-2060.

better. The RCP 4.5 simulation, where anthropogenic impacts on the greenhouse effect stabilize around 2100 at values analogous to a two-thirds increase in $\mathrm{CO}_{2}$, is in closest agreement with the observations $\left(r^{2}=0.76\right.$, bias $\left.=2 \%\right)$. We interpret this as being an artefact of forcing data; the Earth system model used to drive the runoff simulation over this time period does not capture recently observed unusual North Atlantic Oscillation activity, which is attributed to natural variability ${ }^{17}$. Overall, the SLInG model captures the historical trend in inland lake migration well, including the rapid upturn since 1996 during which observations are most abundant, providing confidence in the model's capacity to simulate SGL evolution.
Our simulations suggest that SGLs will continue to spread inland over the coming decades, at an intermediate rate that is faster than during the earliest period of our experiment (1971-1995), but slower than the rapid migration of recent decades (Fig. 2). Under RCPs 4.5 and 8.5, simulated SGLs spread inland in southwest Greenland at $1.5 \pm 1.0$ and $1.2 \pm 1.3 \mathrm{~km} \mathrm{yr}^{-1}$ respectively, between 2013 and 2045-about half the present rate. This slowdown is attributed to a return to climatological North Atlantic Oscillation conditions in the forcing data. The relative uncertainty of both trends reflects the variability in runoff over intermediate timescales, driven by the underlying complexity in the climate system. The maximum altitude at which SGLs appear in our simulations 


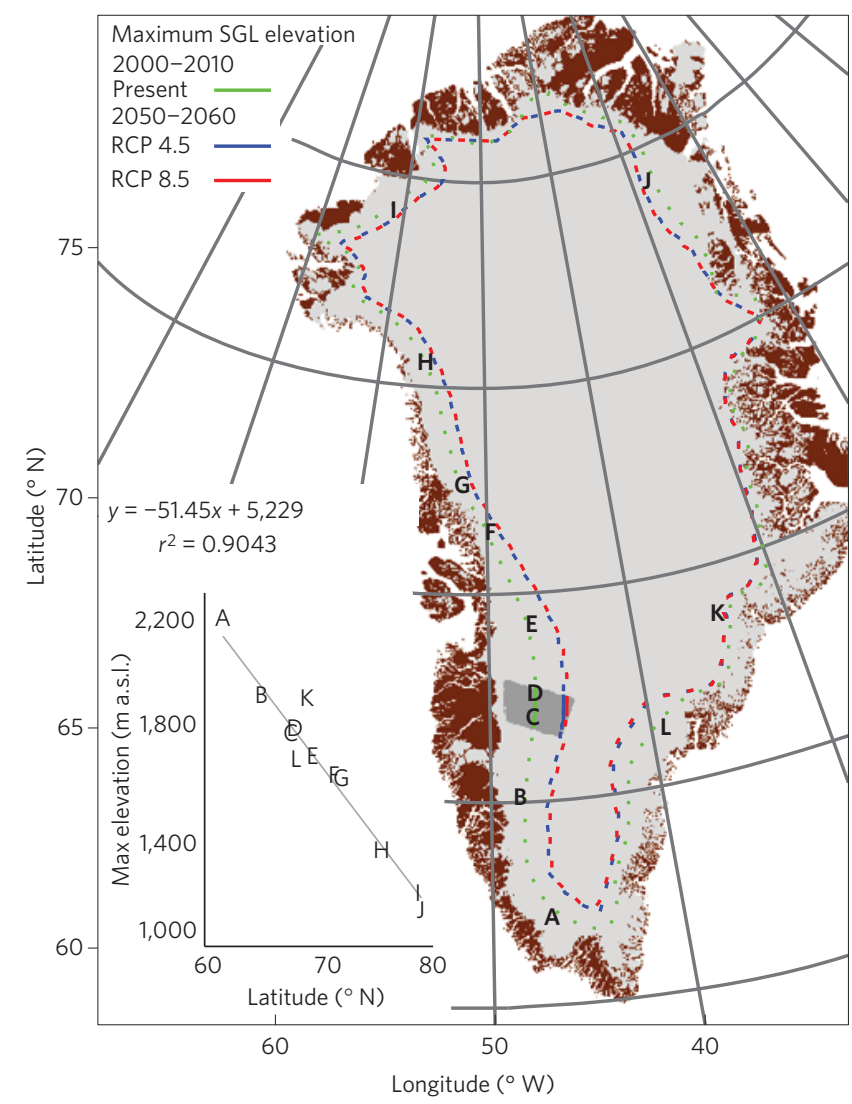

Figure 3 | Future inland migration of SGLs on the Greenland ice sheet. Maximum elevation of SGLs at present and in the future; solid lines indicate simulated/observed values; dashed lines indicate extrapolated values. Grey shading indicates SLInG model domain for experiments described here. Inset shows relationship used for extrapolation, which is based on average maximum SGL elevation, observed between 2000 and 2010; mapped letters indicate location of observations.

stabilizes at around 2,200 m a.s.l. shortly after 2045 under both RCPs (Fig. 2). However, this altitude coincides with the lateral extent of the elevation model used in our simulations, and it seems likely that this constitutes a lower limit given that runoff occurs farther inland in regional climate model projections beyond this date. We simulate that, under RCPs 4.5 and 8.5, SGLs will be found at 2,191 $\mathrm{m}$ a.s.l. and $2,221 \mathrm{~m}$ a.s.l., in at least five of the years between 2050 and 2060, increases of $399 \mathrm{~m}$ a.s.l. and $429 \mathrm{~m}$ a.s.l., respectively, compared with the present day (Table 1). This $103-110 \mathrm{~km}$ inland migration corresponds to a $10,537-11,283 \mathrm{~km}^{2}(94-101 \%)$ increase in the area of ice over which SGLs are distributed (Fig. 1 and Table 1).
SGLs are abundant and sparse below and above 1,600 $\mathrm{m}$ a.s.l. in our study area, respectively (Figs 1 and $2 \mathrm{~b}$ ), following undulations in the bedrock topography, which are damped according to the thickness of the overlying $i^{2}$. In our simulations of lake distributions, these depressions tend to appear in regions where basal slope is lower than average ( $60 \%$ of lakes) or where the bedrock is relatively smooth (61\% of lakes; Supplementary Table 2 ), although a more detailed analysis of these relationships will probably require bed elevation data of higher resolution than is available at present. On the basis of our SLInG model experiments-in particular the simulation of large lakes at high altitudes-it seems reasonable to suppose that SGLs will develop at, or near to, the ice divide in this sector of Greenland (around 2,500 $\mathrm{m}$ a.s.l.) before 2100. Positive runoff is predicted at $2,500 \mathrm{~m}$ a.s.l. in the regional climate model projections used here by 2050 .

The inland migration of SGLs in southwest Greenland under climate warming has broader implications for evolution of the icesheet hydrology and flow elsewhere. To investigate, we derived an empirical relationship between the maximum elevation of SGLs and their latitude (Methods) as a basis for extending our findings to other ice-sheet sectors, assuming that the terrain, firn and runoff in other regions are similarly conducive to future lake formation. Under these assumptions, 550,000 and 570,000 $\mathrm{km}^{2}$ (32 and 33\%) of the ice-sheet surface would be populated by lakes by 2060 under RCPs 4.5 and 8.5 , respectively (Fig. 3 ), a $48-53 \%$ increase relative to the present day $\left(372,000 \mathrm{~km}^{2}\right)$. This extrapolation is least certain in the east and southeast of the ice sheet, where maximum lake elevation and latitude show the poorest correlation (Supplementary Table 1 and Fig. 3). We attribute this to the steep ice-sheet terrain and runoff gradients typical of these areas, each of which present limitations to lake formation.

The rate of melting at the base of SGLs is approximately double that of the surrounding ice, owing to their relatively low albedo $^{20}$, and so an expansion of SGL-covered area may also lead to increased melting. On the basis of our simulations, and extrapolating across the entire ice sheet (Methods), we estimate that increases in the population of SGLs will lead to a $0.7-0.8 \%$ increase in the volume of surface melting (6.61-8.54 $\left.\mathrm{Gt} \mathrm{yr}^{-1}\right)$ in Greenland-more than twice that which lakes contribute today. This is probably an upper limit as roughly half of SGLs are thought to drain at some point during the melt season ${ }^{12}$, and so their potential impact on ice-sheet mass balance through albedo changes alone is relatively modest.

Even though the processes controlling rapid lake drainage are not well understood, linear elastic fracture mechanics can be used to identify lakes that are large enough to hydro-fracture ${ }^{13,21}$. When applied to SGLs that we simulate above the present-day maximum elevation in 2060 in southwest Greenland (Methods), we estimate, on the basis of a sensible range of sensitivity values, that between 4 and $58(4-51 \%)$ and 12 and $72(8-50 \%)$ are large

Table 1 | Simulated changes in supraglacial lake distribution.

\begin{tabular}{|c|c|c|c|c|c|}
\hline & \multirow[b]{2}{*}{ 2000-2010 } & \multicolumn{2}{|c|}{ RCP 4.5} & \multicolumn{2}{|c|}{ RCP 8.5} \\
\hline & & $2050-2060$ & Change & $2050-2060$ & Change \\
\hline Mean lake size $\left(\mathrm{km}^{2}\right)$ & 0.60 & 0.68 & 0.08 & 0.72 & 0.12 \\
\hline Number of lakes & 459 & 613 & 154 & 652 & 193 \\
\hline Lake area $\left(\mathrm{km}^{2}\right)$ & 276 & 417 & 141 & 473 & 197 \\
\hline Lake-covered area $\left(\mathrm{km}^{2}\right)$ & 7,976 & 18,517 & 10,537 & 19,265 & 11,283 \\
\hline Maximum elevation of lake-covered area (m a.s.l.) & 1,677 & 2,191 & 399 & 2,221 & 429 \\
\hline Elevation of 90th percentile of lake-covered area ( $m$ a.s.I.) & 1,534 & 1,747 & 307 & 1,958 & 518 \\
\hline
\end{tabular}

Lake-covered area represents the total area over which lakes are spread; lake area represents the sum of the maximum area attained by each individual lake. Decadal values relate to lakes simulated in SLInG model grid cells in at least five model years. The model domain is limited to the region above 1,100 $\mathrm{m}$ a.s.l., where ice-sheet dynamics are sensitive to the effects of surface melting ${ }^{10,15}$; a $3,213 \mathrm{~km}^{2}$ region below this is already populated by lakes. 
enough to hydro-fracture, thus making melt water available for basal lubrication and cryo-hydrologic warming, under RCPs 4.5 and 8.5 respectively. We use the Shreve hydraulic potential equation ${ }^{22}$ to map likely subglacial drainage pathways, were surface water to access the bed (Fig. 1, Methods). We find that the simulated SGLs form in locations allowing easy access to the subglacial hydrologic (potential) network in the event of drainage (220 m away on average). This suggests that if lakes drain at higher elevations than observed at present in coming years, the subsequent impact on basal sliding is likely to propagate downstream.

Although the Arctic region is predicted to warm by $2.2-8.3^{\circ} \mathrm{C}$ by 2100 (ref. 23), simulations of Greenland ice-sheet evolution have not considered the impact of changes in the distribution of SGLs that impact on the ice-sheet surface albedo ${ }^{20}$ and, when they drain, on ice flow through basal lubrication ${ }^{3}$ and en-glacial ice warming ${ }^{5}$. According to our simulations, even in a warmer climate the impact of SGLs on the area-averaged albedo of the ice sheet remains small. However, by 2060 , we show that $94-108 \%$ more of our study area will host SGLs and become exposed to their influence on ice flow. Extending the results of our model, we estimate that $48-53 \%$ more of the ice sheet will be similarly affected. Ice in these inland areas has been shown to exhibit a positive dynamical response to increased runoff ${ }^{11}$, in contrast to that at lower elevations, where the effects of enhanced basal ice lubrication are offset by efficient subglacial drainage ${ }^{6}$.

The latest ice-sheet modelling studies suggest that between 0 and $27 \%$ of Greenland's projected contribution to global sea level (0.05-0.22 m; ref. 23) can be attributed to the impact of seasonal melt on ice-sheet dynamics ${ }^{24,25}$. However, these estimates are based on observations of melt-induced acceleration that have a narrow spatio-temporal extent ${ }^{4}$ and do not consider the potential effects of cryo-hydrologic warming. ${ }^{5}$. Our study demonstrates that SGLs large enough to drain will in fact spread far into the ice-sheet interior as climate warms, which suggests that projections of the ice-sheet dynamical imbalance should be revised to account for the expected evolution in their distribution. Establishing the degree to which the inland spread of SGLs will affect future ice-sheet motion is now a matter of considerable concern.

\section{Methods}

Simulation of SGLs. SLInG is a hydrologic model that uses Manning's equation for open channel flow and Darcy's law for flow through a porous medium to route and pond water over a digital elevation $\operatorname{model}^{8}$ (DEM). The SLInG model has been shown to successfully reproduce observed supraglacial lake evolution at both the seasonal and inter-annual timescales ${ }^{8}$. The DEM used in this study was generated using Interferometric Synthetic Aperture Radar data acquired in the winter of 1995/1996 by the European Remote Sensing satellites (ERS-1 and ERS-2). By comparison with IceSat altimetry measurements, the DEM is estimated to reproduce the vertical location of the ice-sheet surface to within $11.8 \mathrm{~m}$ (root mean squared deviation) with a precision $\left(r^{2}\right)$ of 1.0. The DEM extends farther inland than previous high-resolution models, and exhibits surface depressions farther inland than the current upper limit of SGL formation.

Three model experiments were performed using runoff estimates derived from version 2 of the Modèle Atmosphérique Régional (MAR) regional climate model, which includes a comprehensive snow model that explicitly accounts for the retention and refreezing of runoff ${ }^{18}$. These comprised an experiment covering the 1971-2010 period (past and present) and two experiments covering the 2010-2100 period (future) under moderate and extreme climate scenarios characterized by RCPs 4.5 and 8.5 respectively. Global mean temperature change under RCPs 4.5 and 8.5 is projected to be $1.8^{\circ} \mathrm{C}\left(1.1-2.6^{\circ} \mathrm{C}\right)$ and $3.7^{\circ} \mathrm{C}$ $\left(2.6-4.8^{\circ} \mathrm{C}\right)$ by 2100 . MAR was forced at the boundaries by the European Centre for Medium-Range Weather Forecasts ERA-40 reanalysis for simulations covering 1971-1989 and the ERA-Interim reanalysis for simulations covering 1990-2010. For future simulations, MAR was forced by the Canadian Earth System Model (CanESM2) from the CMIP5 database (used in the Intergovernmental Panel on Climate Change fifth assessment report). CanESM2 has been shown to successfully reproduce the atmospheric circulation in the $\operatorname{Arctic}^{26}$

Estimate of SGL drainage. The amount of water required to hydro-fracture thick ice is linearly related to ice thickness, where the slope of this relationship is determined by the shear modulus of the ice ${ }^{21}$. The shear modulus of ice depends on multiple factors that, for thick ice sheets, are imperfectly understood (for example, strain rate, grain size, impurities and temperature $)^{27}$. However, within a range of sensible values (3.9-0.32 GPa; ref. 27), SGLs are required to be larger than $0.13 \mathrm{~km}^{2}-0.5 \mathrm{~km}^{2}$ for hydro-fracture to occur through $\sim 1 \mathrm{~km}$ of ice $\mathrm{e}^{21}$. Extrapolating this relationship forward, we estimate that to hydro-fracture $\sim 2 \mathrm{~km}$ of ice, SGLs need to have an area greater than $0.18 \mathrm{~km}^{2}-2.14 \mathrm{~km}^{2}$, depending on shear modulus. In our simulations, $51 \%$ and $4 \%$ of SGLs that form above the present-day maximum elevation in 2060 under the RCP 4.5 scenario have an area greater than $0.18 \mathrm{~km}^{2}$ and $2.14 \mathrm{~km}^{2}$ respectively. Under RCP $8.5,50 \%$ and $8 \%$ of SGLs meet these criteria.

Ice-sheet-wide extrapolation. The maximum elevation at which lakes are found $\left(z_{\max }\right)$ is close to the ice-sheet equilibrium line altitude (Supplementary Table 1), which, in turn, has been described as a function of latitude ${ }^{28}(L)$. We follow this approach and use satellite observations of the average maximum lake elevation at 12 sites $^{9}$ over the period 2000-2010 to develop an empirical model (equation (1), $\left.r^{2}=0.9\right)$ to describe the spatial variation in $z_{\max }$

$$
z_{\max }=51.45 L+5,229
$$

Estimate of SGL-enhanced melting. We characterized the impact, $I$, of SGLs on melting by percentage additional melt with respect to bare ice. We calculate $I$ by assuming that the melt rate $(\dot{\alpha})$ beneath SGLs is twice that of the surrounding ice and using equation (2). Total lake area $\left(A_{\text {lakes }}\right)$ is estimated for the entire ice sheet by multiplying lake density modelled in the study region by the total lake-covered area (including that which lies below $1,100 \mathrm{~m}$ a.s.l.) observed in the present and simulated in the future.

$$
I=100 *\left(\frac{\left(\dot{\alpha}_{\text {ice }} \times A_{\text {ice }}+\dot{\alpha}_{\text {lakes }} \times A_{\text {lakes }}\right)}{A_{\text {total }}}-\frac{\dot{\alpha}_{\text {ice }} \times A_{\text {total }}}{A_{\text {total }}}\right)
$$

Subglacial hydrology. A hydraulic potential field was calculated using Shreve's hydraulic potential equation and DEMs of the ice surface and bed ${ }^{29}$, under the assumption that the ice sheet is warm-based; equation (3).

$$
\varphi=\rho_{w} g h+P_{\mathrm{w}}
$$

where $h$ is the bedrock elevation and $P_{\mathrm{w}}$ is the subglacial water pressure. Here we assume that the effective pressure is negligible compared with ice overburden pressure and thus $P_{\mathrm{w}}$ can be represented by ice overburden pressure alone: $\rho_{i} g H$, where $H$ is ice thickness.

Spatial analysis tools in ArcMap were used to calculate the preferential flow direction of each cell in the hydrologic potential field and the corresponding potential accumulation for each cell. Cells with higher than average accumulation were assumed to form a subglacial hydrologic network. Individual catchments were identified on the basis of their exit point at the ice-sheet margin.

\section{Received 29 July 2014; accepted 10 November 2014;} published online 15 December 2014

\section{References}

1. Leeson, A. A. et al. A comparison of supraglacial lake observations derived from MODIS imagery at the western margin of the Greenland ice sheet. J. Glaciol. 59, 1179-1188 (2013).

2. Lampkin, D. J. \& VanderBerg, J. A preliminary investigation of the influence of basal and surface topography on supraglacial lake distribution near Jakobshavn Isbrae, western Greenland. Hydrol. Process. 25, 3347-3355 (2011).

3. Das, S. B. et al. Fracture propagation to the base of the Greenland ice sheet during supraglacial lake drainage. Science 320, 778-781 (2008).

4. Zwally, H. J. et al. Surface melt-induced acceleration of Greenland ice-sheet flow. Science 297, 218-222 (2002).

5. Phillips, T., Rajaram, H. \& Steffen, K. Cryo-hydrologic warming: A potential mechanism for rapid thermal response of ice sheets. Geophys. Res. Lett. 37, L20503 (2010)

6. Sole, A. et al. Winter motion mediates dynamic response of the Greenland ice sheet to warmer summers. Geophys. Res. Lett. 40, 3940-3944 (2013).

7. Sundal, A. V. et al. Melt-induced speed-up of Greenland ice sheet offset by efficient subglacial drainage. Nature 469, 522-524 (2011).

8. Leeson, A. A., Shepherd, A., Palmer, S., Sundal, A. \& Fettweis, X. Simulating the growth of supraglacial lakes at the western margin of the Greenland ice sheet. Cryosphere 6, 1077-1086 (2012).

9. Howat, I. M., de la Peña, S., van Angelen, J. H., Lenaerts, J. T. M. \& van den Broeke, M. R. Expansion of meltwater lakes on the Greenland ice sheet. Cryosphere 7, 201-204 (2013). 
10. Schoof, C. Ice-sheet acceleration driven by melt supply variability. Nature 468, 803-806 (2010).

11. Doyle, S. H. et al. Persistent flow acceleration within the interior of the Greenland ice sheet. Geophys. Res. Lett. 41, 899-905 (2014).

12. Selmes, N., Murray, T. \& James, T. D. Characterizing supraglacial lake drainage and freezing on the Greenland ice sheet. Cryosphere Discuss. 7, 475-505 (2013).

13. Van der Veen, C. J. Fracture propagation as means of rapidly transferring surface meltwater to the base of glaciers. Geophys. Res. Lett. 34, L01501 (2007).

14. Meierbachtol, T., Harper, J. \& Humphrey, N. Basal drainage system response to increasing surface melt on the Greenland ice sheet. Science 341, 777-779 (2013)

15. Chandler, D. M. et al. Evolution of the subglacial drainage system beneath the Greenland ice sheet revealed by tracers. Nature Geosci. 6, 195-198 (2013).

16. Hanna, E., Mernild, S. H., Cappelen, J. \& Steffen, K. Recent warming in Greenland in a long-term instrumental (1881-2012) climatic context: I. Evaluation of surface air temperature records. Env. Res. Lett. 7, 045404 (2012).

17. Fettweis, X. et al. Important role of the mid-tropospheric atmospheric circulation in the recent surface melt increase over the Greenland ice sheet. Cryosphere 7, 241-248 (2013).

18. Fettweis, X. et al. Estimating the Greenland ice sheet surface mass balance contribution to future sea level rise using the regional atmospheric climate model MAR. Cryosphere 7, 469-489 (2013).

19. Van Vuuren, D. P. et al. The representative concentration pathways: An overview. Climatic Change 109, 5-31 (2011)

20. Tedesco, M. et al. Measurement and modeling of ablation of the bottom of supraglacial lakes in western Greenland. Geophys. Res. Lett. 39, L02502 (2012).

21. Krawczynski, M. J., Behn, M. D., Das, S. B. \& Joughin, I. Constraints on the lake volume required for hydro-fracture through ice sheets. Geophys. Res. Lett. 36, L10501 (2009).

22. Shreve, R. L. Movement of water in glaciers. J. Glaciol. 11, 205-214 (1972).

23. Church, J. A. et al. in Climate Change 2013: The Physical Science Basis (eds Stocker, T. F. et al.) Ch. 13, 1137-1216 (IPCC, Cambridge Univ. Press, 2013).

24. Parizek, B. R. \& Alley, R. B. Implications of increased Greenland surface melt under global-warming scenarios: Ice sheet simulations. Quat. Sci. Rev. 23, 1013-1027 (2004).
25. Shannon, S. R. et al. Enhanced basal lubrication and the contribution of the Greenland ice sheet to future sea-level rise. Proc. Natl Acad. Sci. USA 110 , 14156-14161 (2013)

26. Belleflamme, A., Fettweis, X., Lang, C. \& Erpicum, M. Current and future atmospheric circulation at $500 \mathrm{hPa}$ over Greenland simulated by the CMIP3 and CMIP5 global models. Clim. Dynam. 41, 2061-2080 (2012).

27. Vaughan, D. G. Tidal flexure at ice shelf margins. J. Geophys. Res. 100, 6213-6224 (1995).

28. Zwally, H. J. \& Giovinetto, M. B. Balance mass flux and ice velocity across the equilibrium line in drainage systems of Greenland. J. Geophys. Res. 106, 33717-33728 (2001)

29. Morlighem, M., Rignot, E., Mouginot, J., Seroussi, H. \& Larour, E. Deeply incised submarine glacial valleys beneath the Greenland ice sheet. Nature Geosci. 7, 418-42 (2014).

\section{Acknowledgements}

This work was supported by the UK National Centre for Earth Observation. We also acknowledge M. van den Broeke who supplied surface mass balance estimates produced using the RACMO model to I.H.

\section{Author contributions}

A.A.L. and A.S. designed the research. A.A.L. wrote and developed the SLInG model and performed all simulations/analysis. K.B. and A.A.L. created the surface DEM used as input into the SLInG model. X.F. provided runoff data from MAR simulations. M.M. and E.R. provided the bedrock DEM. I.H. provided satellite observations and equilibrium line altitude estimates. A.A.L. and A.S. wrote the paper. All authors discussed the results and commented on the manuscript.

\section{Additional information}

Supplementary information is available in the online version of the paper. Reprints and permissions information is available online at www.nature.com/reprints.

Correspondence and requests for materials should be addressed to A.A.L.

\section{Competing financial interests}

The authors declare no competing financial interests. 